\section{Report of the Executive Director}

\section{Catherine E. Rudder}

\section{Introduction}

This has been a solid year for the Association. Under the presidencies of Kenneth N. Waltz and Lucian Pye, we successfully hosted the World Congress of the International Political Science Association, held our largest Annual Meeting in recent years with almost 4200 registrants, published a Biographical Directory for the first time in a decade and a half, hosted a delegation from the Chinese Association of Political Science to four cities in the U.S., created four new Organized Sections, completed our fourth annual Ralph Bunche Summer Institute for Black Undergraduates, established a new Departmental Services Program for High Schools, increased membership by over $15 \%$, completed the computerization of our national office, and turned an anticipated deficit into a surplus.

At the same time, we have confronted some problems. Some of them; like providing adequate professional liability insurance for the members of the Professional Ethics Committee, have been resolved. Others, like the allocation of panels at the Annual Meeting across the various segments of the program, will continue to be discussed throughout the Association, but have found at least tentative solutions

\section{APSA and the World}

China. With the help of the Asia Foundation over the last four years, APSA has sent two delegations to meet with political scientists in China, and last Fall we received a Chinese delegation in the U.S. These official exchanges between the Chinese Association of Political Science and APSA left those who participated hopeful that a new period of collaboration between our scholars had begun. However, as the enormity of the Chinese government's decision to crack down on dissidents begins to settle in, it becomes clear that our political and professional hopes for the PRC may have been too sanguine.

In the course of our visits and other contacts, we have made many good friends among Chinese scholars of politics and law, especially at the Chinese Academy of Social Science (CASS). Because their lives and careers may now be in danger, our most immediate concern is for the safety of our Chinese colleagues and for their ability to resume their scholarly activities unimpeded by government harassment.

Until we obtain more complete information with regard to how APSA might play a helpful role, however, our wisest course has been to watch and wait. In the meantime, under the guidance of the Committee on International Political Science, Associate Director Robert Hauck has continued to pursue other international projects.

Soviet Union. This summer President Pye is leading an APSA delegation to the Soviet Union to continue our IREX-funded exchange with the Soviet Political Science Association. The agenda for this meeting is to discuss research on political reform and to consider ways Soviet and U.S. political scientists might engage in more collaborative research.

As a profession, we have many fewer joint projects underway with the Soviets than other, less politically sensitive disciplines have. However, glasnost and political science go hand-in-hand, as Samuel Huntington reminded us in his Presidential Address. Political science knowledge is informing the development of new, representative institutions in the Soviet Union, and the work of political scientists is facilitated by access to documents, openness of governmental proceedings, and ability to pursue scholarly interests wherever they might lead

Japan. Rob Hauck has begun efforts, as well, to establish an exchange with the Japanese Association of Political Science with the help of the Japan-U.S. Friendship Commission. One part of this project will be to encourage Japanese political scientists to participate in APSA's annual meetings and U.S. scholars to attend conferences in Japan 
Annual Meeting Participants In this regard, we have made a major attempt to increase the number of scholars from outside the U.S. at our Annual Meeting. While financial support is relatively scarce for this purpose, we have been moderately successful in this effort to broaden scholarly interchange at our meetings.

International Conference on Environmental Change. Harold Jacobson, APSA's representative on the Executive Committee of the International Political Science Association and IPSA's Vice President, is planning an international conference, hosted by APSA, on political science research in the area of global environmental change. This topic has become a major initiative at the National Science Foundation (NSF) and constitutes an opportunity for social scientists to obtain NSF research support.

Thanks in part to the efforts of the Consortium of Social Science Associations (to which we belong and whose President is political scientist Raymond Wolfinger), there seems to be increasing recognition that chemical and biological science alone cannot stem environmental deterioration. An understanding of bargaining, international cooperation, human behavior and the functioning of political institutions are necessary as well. Our conference will examine some of these social science aspects of global change

South Africa. The Association is continuing its commitment to developing a graduate fellowship program in political science for black South Africans. An expanded cohort of South African political scientists can make critical contributions to the analysis of African politics as well as provide leadership for educational reform in South Africa. We are working with the Ford Foundation and the Institute of Inter national Education's South Africa Education Program to implement a fellowship program in the near future

Journals to Subsahoran Africa. Finally, in a cooperative venture with the American Council of Learned Societies and the American Association for the Advancement of Science, APSA is donating 25 subscriptions to the APSR and PS. Political
Science and Politics to university libraries in Subsaharan Africa where there would otherwise be no access to these materials.

\section{Education}

In addition to research and exchanges, APSA's international programs extend into the educational area as well. Director of Educational Affairs Sheilah Mann is working to improve instruction in comparative politics in the high schools and to provide materials for introductory comparative politics courses at both the collegiate and secondary levels. With the advent of Advanced Placement comparative government courses in high schools, there is a particular need for this kind of effort.

I am pleased to report that our new Departmental Services Program for High Schools is proceeding quite well. Already over 70 high schools have enrolled in the program which includes a series of panels on Saturday at our Annual Meeting of especial interest to high school government teachers.

Sheilah Mann has also obtained funding from the Ford Foundation to hold four seminars for college teachers on civil rights. Eighty APSA members will attend these sessions to be held in Atlanta immediately before our Annual Meeting.

With the second highest number of majors of any social science discipline, political science continues to thrive at the undergraduate level. Moreover, even more bright, serious students should be attracted to major in political science as the Advanced Placement Program introduces excellent high school students to our discipline. The data from the College Board show that these students are more likely to take political science courses in college

It has become increasingly apparent, however, that there is a need for recommended political science curricula for precollege education, as well as a need for guidelines concerning what courses in political science would adequately prepare high school government teachers. Most other social science disciplines provide these kinds of statements to give guidance to 
those planning curricula for college students. Soon politicai science will as well.

Working with the Association of American Colleges, APSA has assembled a task force to examine the political science undergraduate major. In addition, the Education Committee has initiated a survey to determine which states have laws mandating high school and college American government courses and whether those without such requirements might institute them.

Finally, with regard to educational materials, we will soon have a series of software teaching packages, authored by Steve Frantzich and funded by IBM, available for distribution to the profession, and a SETUPS based on the 1988 National Election Study.

\section{Minority Affairs}

One of APSA's most important projects for the future of the discipline is the Ralph Bunche Summer Institute for Black Undergraduates. This program assists black students in deciding whether to pursue an academic career in political science and helps prospective students have successful graduate careers.

Now in its fourth and final year under a Ford Foundation grant, the Institute and its effect on recruitment and retention of black students into graduate study are being assessed. Over the next decade, Peter Zwick of Louisiana State University and Jewel Prestage of Southern University, founding Directors of the Institute, plan to follow the careers of students who have attended the Institute. As part of our assessment effort, in the Summer of 1990 we will hold a conference in Baton Rouge of students who attended one of the four Institutes.

The directors and instructors of the Institute will be honored for their pioneering efforts at the Friday nightcap reception of the Committee on the Status of Blacks in the Profession at the Annual Meeting in Atlanta. Our profession owes a great debt of gratitude to LSU and Southern and all those political scientists there and elsewhere who have contributed their time and energy to turn the idea of the Institute into a reality.

While 1989 marks the last year of this grant, we are making every effort to replicate this remarkable program in future years. A consortium of four Atlanta schools-Spelman College, Morehouse College, Emory University and Georgia State University-have proposed to hold Bunche Institutes in Atlanta in the summers of 1990 and 1991, and we are hopeful that funding will be forthcoming.

Maurice Woodard, who directs APSA's minority programs, has reported that the APSA Graduate Fellowship Program for Black Americans dovetails well with the Bunche Institute. Over the last three years, most of our Graduate Fellows had attended the Institute.

On a less positive note, however, no one was granted APSA's Graduate Fellowship for Chicanos due to a lack of candidates this year. This fact suggests a severe deficiency in our recruitment of Chicanos into the profession and a need to increase our efforts in this area.

\section{Membership}

Individual membership in APSA continues to grow both among students and professionals whose ranks increased by over 750 from January 1988 to January 1989 (see Table 1). Our latest June fgures show a net increase of 1,453 individual members over last June, a figure which represents an annual growth rate of $15.6 \%$. Our institutional membership is holding steady.

\section{Organized Sections and the Annual Meeting}

The number of groups forming to become Organized Sections is growing as is the number of members affiliated with those Sections. The four new Organized Sections approved at the last two Council meetings are International Security and Arms Control, Comparative Politics, Politics and Society in Western Europe, and State Politics and Policy (see Table 2) 
Table I. APSA Members, 1974-89

\begin{tabular}{ccccccccc}
\hline Year* & Regular & Associate & Student & Retired & Life & Family & $\begin{array}{c}\text { Total } \\
\text { Individual }\end{array}$ & Institutional \\
\hline 1974 & 7,793 & & 4,006 & 217 & 101 & 137 & 12,254 & 3,504 \\
1975 & 7,335 & & 3,912 & 206 & 100 & 149 & 11,702 & 3,648 \\
1976 & 7,428 & & 3,603 & 245 & 96 & 134 & 11,506 & 3,588 \\
1977 & 7,228 & & 3,076 & 270 & 95 & 142 & 10,811 & 3,466 \\
1978 & 7,094 & & 2,655 & 301 & 97 & 154 & 10,301 & 3,338 \\
1979 & 6,845 & & 2,335 & 310 & 91 & 148 & 9,729 & 3,339 \\
1980 & 6,592 & & 2,159 & 344 & 91 & 135 & 9,321 & 3,337 \\
1981 & 6,423 & & 1,901 & 349 & 92 & 129 & 8,894 & 3,283 \\
1982 & 5,838 & & 1,984 & 388 & 97 & 134 & 8,441 & 3,156 \\
1983 & 5,764 & & 2,068 & 382 & 104 & 130 & 8,448 & 3,018 \\
1984 & 5,891 & & 2,511 & 378 & 111 & 151 & 9,042 & 3,059 \\
1985 & 5,879 & 106 & 2,595 & 411 & 116 & 166 & 9,273 & 2,996 \\
1986 & 6,009 & 145 & 2,589 & 432 & 117 & 173 & 9,465 & 3,046 \\
1987 & 5,913 & 154 & 2,775 & 439 & 127 & 202 & 9,610 & 3,109 \\
1988 & 6,171 & 173 & 2,728 & 450 & 129 & 186 & 9,837 & 2,975 \\
1989 & 6,445 & 249 & 3,054 & 489 & 166 & 192 & 10,595 & 2,948 \\
\hline
\end{tabular}

*January of each year.

Table 2. Organized Section Members, 1989

\begin{tabular}{lc}
\hline Organized Section & $\begin{array}{c}\text { Number of } \\
\text { Members }\end{array}$ \\
\hline Federalism and Intergovern- & 505 \\
mental Relations & 772 \\
Law, Courts and Judicial Process & 656 \\
Legislative Studies & 621 \\
Policy Studies & \\
Political Organizations and & 491 \\
Parties & 653 \\
Public Administration & 257 \\
Conflict Processes & \\
Representation and Electoral & 282 \\
Systems & 419 \\
Presidency Research & 332 \\
Political Methodology & 335 \\
Religion and Politics & 111 \\
Politics and Life Sciences & 357 \\
Urban Politics & 193 \\
Applied Political Science & 207 \\
Science and Technology & 424 \\
Women and Politics & 675 \\
Foundations of Political Theory & 215 \\
Computer Users & \\
International Security Arms & 270 \\
Control & 369 \\
Comparative Politics & \\
Politics and Society in Western & forming \\
Europe & forming \\
State Politics and Policy & \\
\hline
\end{tabular}

As Organized Sections become an integral part of the Association, those leading them and the Council have been working to adapt APSA to fundamental organizational change. This need became most obviously apparent in connection with the allocation of panels at the Annual Meeting. Because of the importance of this issue to the future of the Association, I would like to report in some detail on it.

Stage One. In 1987 the Council established an ad hoc Committee on the Structure of the Annual Meeting which included representatives from unaffiliated groups, Organized Sections, past Program Chairs, and the Council Committee on Organized Sections. This ad hoc committee made the first systematic effort to institutionalize the role of Organized Sections at the Annual Meeting and to allocate a mandated proportion of panels for each of the three elements of the Program which include the Sections of the Program Committee $(50 \%)$, the Organized Sections (30\%), and unaffiliated groups (20\%).

The Council accepted this recommendation and agreed that all panels should, as far as possible, be held in the headquarters hotel. This stricture, which varies as the size of our Annual Meeting hotels vary, 
Table 3. Budget Summary, 1979-89

\begin{tabular}{lrrr}
\hline Year & Income & Expenditures & Surplus \\
\hline $1979-80$ & $\$ 930,157$ & $\$ 929,857$ & $\$ 300$ \\
$1980-81$ & $1,007,675$ & 977,328 & 30,347 \\
$1981-82$ & $1,117,201$ & $1,043,255$ & 74,446 \\
$1982-83$ & $1,202,078$ & $1,094,415$ & 107,663 \\
$1983-84$ & $1,323,074$ & $1,247,529$ & 75,545 \\
$1984-85$ & $1,415,077$ & $1,353,334$ & 54,738 \\
$1985-86$ & $1,505,224$ & $1,453,248$ & 51,976 \\
$1986-87$ & $1,585,000$ & $1,500,000$ & 85,307 \\
$1987-88$ & $1,637,637$ & $1,563,252$ & 74,385 \\
$1988-89^{*}$ & $1,804,570$ & $1,734,457$ & 70,113 \\
\hline
\end{tabular}

*Projected

imposes a limit on the total number of panels which are offered at our meetings and creates competition for space.

As a consequence, for the first time in recent years, the executive director has had a major role in parceling out the number of panels available to each Organized Section and unaffiliated group. The 1988 Program Chairs, John Ferejohn and Steve Krasner, distributed their allocated space (50\% of the total) at their discretion among the Program Sections.

In distributing the remaining $50 \%$ to Organized Sections and unaffiliated groups, I followed a formula which guaranteed every group some space and which allocated meeting rooms on the basis of the number of panels each group had had in the past and on the basis of panel attendance relative to that at other panels at the meeting. This formula proved to be an acceptable solution to the problem, and all groups who requested space got some

Stoge Two. In 1989 Program Chair Nelson W. Polsby experimentally merged the Organized Sections with the Official Program. He placed each Organized Section in charge of that part of the Official Program covered by its subject matter We discovered that merging the Organized Sections into the Official Program was no easy matter in part because the subject matter of Organized Sections is not necessarily congruent with that of the Program Sections which, in turn, are not precisely continuous over time.

Stage Three Jane Mansbridge. Program
Chair for 1990, thus inherited an as yet unresolved organizational and intellectual problem. She has wanted to make sure there is adequate space for Organized Sections but also did not want automatically to merge Organized Sections with the Sections of the Official Program.

Throughout the year she has consulted extensively with Organized Section leaders and many others throughout the discipline, the results of which consultation are encapsulated in her article in this section of this issue of PS. Her presentation at the Spring Council meeting led to a potential increase in the proportion of panels allocated to Organized Sections and constituted an effort to rationalize the relationship between Organized Sections and Program Sections rather than to merge them.

The Future. The solution we have worked out for allocating panels for the 1990 meeting will be reviewed by the Council and Organized Sections in the coming months. We hope to come to a more permanent accommodation of all the various intellectual and organizational interests as Organized Sections evolve

\section{The Budget}

We anticipate a surplus of approximately $\$ 70,000$ for $F Y$ 1988-89, an improvement of $\$ 98,300$ over our original projection (see Table 3). This accomplishment is especially remarkable in light of our unusual IPSA obligations, the publishing of the very costly Biographical Directory, and 
the computerization of the ent!re APSA operation last year

Our success stemmed from the following factors:

- A strong economy.

- Record attendance at the 1988 Annual Meeting (see Table 4).

- Successful efforts to increase APSA membership

- Understaffing.

- Implementation of cost control measures.

- Aggressive marketing and promotions of APSA products and services.

- Price increases to match real costs.

- Improved money management.

- Extension of Project ' 87.

- Financial caution in running the IPSA World Congress.

- The IBM computer grant.

- A superb, seasoned staff-both professional and support

As we look to the future, we will have to redouble our efforts in the next fiscal

\section{Table 4. Annual Meeting Registration, 1967-88*}

\begin{tabular}{ll}
\hline 1967 & 2473 (Chicago) \\
1968 & 3723 (Washington, D.C.) \\
1969 & 4142 (New York) \\
1970 & 2397 (Los Angeles) \\
1971 & 2732 (Chicago) \\
1972 & 3380 (Washington, D.C.) \\
1973 & 2312 (New Orleans) \\
1974 & 2773 (Chicago) \\
1975 & 2478 (San Francisco) \\
1976 & 2295 (Chicago) \\
1977 & 2624 (Washington, D.C.) \\
1978 & 2373 (New York) \\
1979 & 2687 (Washington, D.C.) \\
1980 & 2745 (Washington, D.C.) \\
1981 & 2887 (New York) \\
1982 & 2205 (Denver) \\
1983 & 2859 (Chicago) \\
1984 & 3391 (Washington, D.C.) \\
1985 & 2842 (New Orleans) \\
1986 & 3602 (Washington, D.C.) \\
1987 & 3524 (Chicago) \\
1988 & 4161 (Washington, D.C.) \\
\hline
\end{tabular}

* 1972-88 figures include exhibitors registered at the meeting, since their fee for booth rental includes the cost of their registration rable 5. Market Value of APSA Funds, 1981-1989

\begin{tabular}{lcc}
\hline Year* & $\begin{array}{c}\text { Trust and } \\
\text { Development } \\
\text { Fund }\end{array}$ & $\begin{array}{c}\text { Endowed } \\
\text { Program } \\
\text { Funds }\end{array}$ \\
\hline 1981 & $\$ 783,081$ & $\$ 94,118$ \\
1982 & 806,593 & 118,214 \\
1983 & $1,080,985$ & 149,682 \\
1984 & $1,001,775$ & 225,580 \\
1985 & $1,450,032$ & 264,149 \\
1986 & $1,677,365$ & 304,105 \\
1987 & $1,811,794$ & 362,174 \\
1988 & $1,685,345$ & 382,268 \\
1989 (projected) & $1,800,000$ & 400,000 \\
\hline
\end{tabular}

*June 30 of each year

year to forestall what could be a large deficit, even under optimistic assumptions. We have not, I am happy to say, had a dues increase since 1981, but the day of reckoning is coming. Our costs, particularly those associated with printing, one of our primary activities, have escalated much faster than the rate of inflation. I will continue to do everything I can to keep expenses down and to secure non-dues sources of income.

Assets and Awards. Our major assets, the Trust and Development Fund, our Endowed Program Funds which support our awards, and our building, continue to grow in value (see Table 5). The earnings of the Trust and Development Fund, the value of which is $\$ 1.8$ million, will provide $\$ 200,000$ of income for our annual operating budget this year.

Under the leadership of Frank Sorauf, who chaired the ad hoc committee on Awards and the ad hoc Endowed Program Committee, APSA has undertaken a careful review of our Endowed Program Funds. As the result of the work of those two committees, the Council has instituted a policy concerning funding of future awards and has established a Development Committee which will oversee Endowed Program Funds and future development efforts. In addition, the Board of Trustees of the Trust and Development Committee has agreed to invest 
the Endowed Program Funds for the Association

\section{Other Matters}

As you can see from the attached index of reports that have appeared in PS over the past year, we have not been idle as an Association. In addition to the items listed here, you should know that the Guide to Graduate Study, 1989, the Directory of
Department Chairs, and the Survey of Departments are all now available. We have also improved our ability to generate precise mailing lists. This service should be helpful in recruitment and in identifying political scientists for conferences and other special purposes.

If you have ideas for the Association or if you have any questions about our activities, please feel free to give me a call at (202) 483.2512 I look forward to hearing from you

\section{Index of APSA Reports in PS-Summer 1988. Spring 1989}

\section{American Political Science Review}

The Americon Political Science Review: A Retrospective of Last Year and the Last Eight Decades

Fall 1988

908

\section{Annual Meeting-1988}

APSA Awards Ceremony and Presidential Address Changed to Friday APSA/PSA Plenary Sessions

James W. Fesler To Be Honored at Annual Meeting

Elliot L. Richardson To Participate on Annual Meeting Panel

Judge Ginsburg Will Talk on Women and the Constitution

Washington Annual Meeting Breaks All Records

Participation by Women in the 1988 Annual Meeting

Perspectives on American Politics: Domestic and Foreign

Mansbridge Receives Second APSA Award for Why We Lost the ERA

Bourgin Attends Annual Meeting

Foreign Students Attend 1988. APSA and IPSA Meetings with

Grant Support

Gay and Lesbian Political Science Caucus Formed

Annual Meeting-1989

1989 Annual Meeting

Inviting Applications for Seminars on the Bill of Rights and

Civil Rights at 1989 Annual Meeting

1989 Annual Meeting

Plan Now for Atlanta Annual Meeting

Dining in Atlanta

APSA To Offer Short Courses at Annual Meeting

APSA Offers Free Child Care at Annual Meeting

Carter to Speak at Annual Meeting

Wildavsky to Deliver Gaus Lecture

Harold Lasswell Symposium Panel

Advances in Policy Studies, 1950-1990

Preregistration Form

Preliminary Program

1989 Annual Business Meeting Rules
Summer 1988

Summer 1988

Summer 1988

Summer 1988

Summer 1988

Fail 1988

Fall 1988

Fall 1988

Fall 1988

Fall 1988

Fall 1988

Fall 1988

Summer 1988

Fall 1988

Fall 1988

March 1989

June 1989

June 1989

June 1989

June 1989

June 1989

June 1989

June 1989

March 1989

June 1989

June 1989
726

723

724

724

724

725

956

958

961

966

974

974

993

993

94

108

283

290

292

293

293

293

294

112

341

330 